\title{
SISTEM INFORMASI AKUNTANSI MANAJEMEN, SISTEM INFORMASI AKUNTANSI, DAN KINERJA MANAJERIAL
}

\author{
Yana Rochdiana Hadiyat \\ yana.rochdiana@unpas.ac.id \\ Universitas Pasundan \\ Jl. Tamansari No. 6-8, Bandung 40116
}

received: 28/3/2020; revised: 16/4/2020; approved: 28/4/2020

\begin{abstract}
This study aims to determine empirical evidence of the influence of the characteristics of management accounting information systems on managerial performance moderated of accounting information systems. This study found that digital skills and aggregation have a higher influence on managerial performance than the effect of boardscope, timelines, aggregation, and integration. The population in this study were leaders and staff of state-owned enterprises that were limited liability companies in West Java. The number of samples used was seventytwo. The expected benefit is to provide input to the company as a material for consideration in designing a company's management accounting system tailored to business strategy, which has an impact on improving managerial performance.
\end{abstract}

Keywords: boardscope; timelines; aggregation; integration; digital skills; managerial performance

\begin{abstract}
Abstrak
Penelitian bertujuan untuk mengetahui bukti empiris pengaruh karakteristik sistem informasi akuntansi manajemen terhadap kinerja manajerial dimoderasi sistem informasi akuntansi. Studi ini menemukan bahwa digital skills dan aggregation mempunyai pengaruh terhadap kinerja manajerial lebih tinggi dari pada pengaruh antara boardscope, timelines, aggregation, dan integration. Populasi adalah pimpinan dan staf di BUMN yang berbadan hukum perseroan terbatas di Jawa Barat. Jumlah sample yang digunakan sebanyak tujuh puluh dua. Manfaat yang diharapkan adalah memberikan masukan sebagai bahan pertimbangan untuk mendesain sistem akuntansi manajemen disesuaikan dengan strategi bisnis yang memberikan dampak pada peningkatan kinerja manajerial.
\end{abstract}

Kata Kunci: boardscope; timelines; aggregation; integration; digital skills; kinerja manajerial

\section{PENDAHULUAN}

Kinerja manajerial merupakan hal yang penting dalam manajemen secara keseluruhan. Kinerja manajerial dapat diukur dengan keberhasilan manajemen untuk mencapai tujuannya. Kinerja manajerial menjadi nilai tambah dalam meningkatan hasil. Pengendalian dilakukan oleh seorang pimpinan yang disebut dengan manajer. Seorang manajer yang baik ialah manajer yang mengerti konsep tentang kinerja manajerial serta dapat menerapkannya dengan baik dan juga mempertanggungjawabkannya. Faktor yang dapat mempengaruhi kinerja manajerial adalah perencanaan sistem informasi akuntansi manajemen yang merupakan bagian dari sistem pengendalian yang perlu diperhatikan sehingga dapat memberi kontribusi positif dalam mendukung keberhasilan pengendalian internal manajemen (Gordon dan Narayana, 2014).
Pada era globalisasi dan era revolusi industri 4.0 seperti sekarang informasi sangatlah diperlukan untuk suatu organisasi manajemen. Informasi adalah hasil pengolahan data yang memberikan arti dan manfaat. Informasi sangat bernilai potensial karena informasi berkontribusi langsung terhadap berbagai tindakan yang akan dijadikan perencanaan, pengendalian dan pengambilan keputusan manajemen. Perusahaan sekarang ini cenderung menggunakan sistem informasi berbasis komputer karena lebih memudahkan kinerja manajemen. Di bidang akuntansi, pemanfaatan sistem pemrosesan informasi akuntansi berbasis komputer banyak ditawarkan dengan tujuan untuk memberikan kemudahan bagi para penggunanya dan menghasilkan informasi yang dipercaya, relevan, tepat waktu, lengkap, dapat dipahami dan teruji.

Walaupun penggunaan sistem informasi berbasis komputer memiliki kendala dalam biaya yang cukup 
besar, namun perusahaan tetap menggunakannya. Namun dengan adanya sistem informasi berbasis komputer perusahaan mendapatkan manfaat dapat lebih memaksimalkan kinerjanya dari teknologi informasi berbasis komputer. Dengan adanya manfaat yang diperoleh dari teknologi informasi berbasis komputer maka kinerja manajerial dapat lebih meningkat karena manajer 3 mendapatkan informasi yang dapat dipercaya, relevan, tepat waktu, lengkap, dapat dipahami dan teruji untuk suatu pengambilan keputusan. Teknologi informasi (TI) telah menjadi kebutuhan sekaligus persyaratan bagi organisasi dalam menjalankan bisnisnya. Secara prinsip, TI telah menjadi pemungkin (enabler) bagi organisasi dalam rangka mencapai tujuan (Jogiyanto, 2017). Dengan semakin berkembangnya TI, maka dapat mengubah suatu organisasi dalam menjalankan usahanya, sehingga harus dilakukan perencanaan yang hati-hati untuk memastikan bahwa dengan adanya TI mampu meningkatkan pelayanan, efisiensi, dan profitabilitas (Laudon, et. al., 2012).

Akuntansi adalah bahasa bisnis, yang digunakan setiap organisasi sebagai bahasa komunikasi saat berbisnis, yang pada dasarnya merupakan sistem informasi (Susanto, 2017). Akuntansi yang sudah berubah karena perkembangan teknologi, menjadi sistem informasi yang menyediakan laporan kepada para penggunanya mengenai aktivitas ekonomi dan kondisi perusahaan (Warren, et. al., 2012).

Sistem informasi yang baik adalah sistem yang mampu menghasilkan kinerja dan manfaat bagi penggunanya (Abdillah \& Jogiyanto, 2015). Bagi suatu perusahaan, sistem informasi akuntansi (SIA) dibangun dengan tujuan utama untuk mengolah data akuntansi yang berasal dari berbagai sumber menjadi informasi akuntansi yang diperlukan oleh berbagai macam pemakai untuk mengurangi risiko saat mengambil keputusan (Susanto, 2015).

Akuntansi sebagai sistem informasi dikembangkan dengan menggunakan TI untuk menghasilkan kinerja yang lebih baik dan nilai bagi organisasi, sehingga diperlukan pengukuran yang tepat untuk mengukur keberhasilan sistem informasi akuntansi (SIA) (Abdillah \& Hartono, 2017). Pada kenyataannya masih terdapat masalah mengenai tingkat keberhasilan implementasi SIA yang tergabung dalam ERP. Survei yang dilakukan di Amerika pada tahun 2012 (Krigsman, 2012) menunjukkan bahwa 57\% implementasi sistem ERP memakan waktu lebih lama dari yang diharapkan dan $54 \%$ melebihi anggaran yang telah ditetapkan. Selain itu, sebesar 32\% eksekutif dan 39\% pekerja tidak puas dengan implementasi sistem ERP. Kemajuan teknologi informasi menuntut perusahaan di bawah Badan Usaha Milik Negara (BUMN) membuat tata kelola teknologi informasi (IT Governance). Agar perusahaan memiliki mekanisme yang sistematik untuk memenuhi tuntutan regulasi dan kebutuhan bisnis.
Demikian disampaikan pakar IT Governance, Fajar Hidayat, dalam seminar executive dengan tema IT Strategic Plan dalam persiapan membangun IT Masterplan dan IT Governance sesuai dengan Peraturan Menteri BUMN PER02/MBU/2013, di Hotel Shangrilla Surabaya (KOMINFO, 2013).

Menurut(Bashirudin, 2015), (Mauliansyah \& Saputra, 2020), (Rumapea, et. al., 2018), (Suprantiningrum \& Lukas, 2021) terdapat pengaruh karakteristik informasi akutansi manajemen terhadap kinerja manajerial, (Solechan \& Setiawati, 2009), (Pedroso, et. al., 2020), (Alsarayerh \& Jain, 2018), (Mathew, \& Panchanatham, 2016).

(Wilkin \& Chenhall, 2010) menemukan bukti empiris mengenai karakteristik informasi yang bermanfaat menurut persepsi para manajerial, yang terdiri dari empat dimensi, yaitu broadscope, timeliness, aggregated dan integrated.

Menurut Chartered Institute of Management Accountants (CIMA), tim keuangan dan profesional yang tidak mengembangkan skill digital yang merupakan produk teknologi akan ketinggalan dalam kurun waktu 3 tahun. Oleh karenanya profesi bidang keuangan perlu memperbaiki skill dalam bidang tersebut.

Menurut (Choe, 2017), keberhasilan penerapan sistem informasi akuntansi di perusahaan tidaklah mudah untuk dicapai dan sering kali menimbulkan masalah karena dipengaruhi oleh banyak faktor, antara lain: (1) Keterlibatan pemakai; (2) Dukungan pimpinan; (3) Pelatihan dan pendidikan pemakai; (4) Faktor kelompok kerja dalam organisasi; dan (5) Faktor organisasi lainnya seperti ukuran organisasi, karakteristik tugas, dan lain-lain. Menurut (Swanson \& Ramiller, 1997), di samping faktor organisasi seperti kompleksitas tugas, ukuran organisasi, faktor kepemimpinan, dan lain-lain, faktor individual seperti motivasi, kepuasan, dan kebermanfaatan bagi pemakai sangat menentukan keberhasilan penerapan sistem informasi akuntansi. Kemudian (Lee, et. al., 2018) mengatakan bahwa komitmen organisasional mempengaruhi keberhasilan penerapan sistem informasi akuntansi melalui upaya formalisasi pengembangan sistem informasi akuntansi di perusahaan. Dengan formalisasi pengembangan sistem informasi akuntansi, kelemahan dalam pengalaman dan pembelajaran personal pengguna menjadi dapat diatasi. Penelitian tentang karakteristik Informasi sistem akuntansi manajemen yang dihubungkan dengan variabel moderating Sistem Informasi Akuntansi dan Kinerja manajerial telah banyak dilakukan namun terdapat banyak perbedaan dalam berbagai hasil penelitian yang ditemukan. Beberapa penelitian yang telah dilakukan (Fathi, 2015), (Mia \& Chenhall, 1994), (Tsui \& Gul, 1996), menguji pengaruh variabel-variabel kontekstual pada desain sistem akuntansi manajemen dan kinerja manajerial. (Wiryana \& Augustine, 2014) adanya pengaruh interaksi karakteristik informasi sistem akuntansi manajemen dengan strategi bisnis, PEU (perceived environmental uncertainty), ketidakpastian tugas dan desentralisasi secara bersama-sama terhadap kinerja manajerial. 
(Pedroso, et. al., 2020) dalam penelitiannya menemukan bahwa karakteristik informasi akuntansi manajemen berpengaruh terhadap kinerja manajerial. Handayani and Hariyati (2014) hasil penelitiannya menunjukkan bahwa sistem informasi akuntansi manajemen berpengaruh terhadap kinerja manajerial berdampak adanya peningkatan kinerja manajerial. Widodo dan Windi (2011) hasil penelitian yang diperoleh adalah secara parsial baik variabel desentralisasi ataupun karakteristik informasi berpengaruh terhadap kinerja manajerial. (Anik dan Rico, 2018) karakteristik sistem informasi akuntansi manajemen berpengaruh positif secara signifikan terhadap kinerja manajerial.

Sistem informasi akuntansi yang memadai bagi suatu organisasi, ditentukan oleh kemampuan dan kompetensi manajer dalam mengidentifikasi sistem informasi akuntansi yang dibutuhkan oleh organisasinya. Kompleksnya sistem informasi akuntansi, luasnya lingkup transaksi akuntansi yang mencakup semua bagian perusahaan, dan adanya banyak prosedur dalam proses sistem informasi akuntansi mulai dari terjadinya transaksi sampai dihasilkannya laporan keuangan, menuntut seorang manajer keuangan memiliki kapasitas yang memadai untuk melakukan evaluasi atas trouble system dan kemudian mengambil tindakan yang cukup untuk mengatasi permasalahan tersebut, sehingga tidak berdampak terhadap siklus sistem informasi akuntansi secara keseluruhan (Anwar, 2012).

\section{METODE}

Penelitian ini menggunakan metode survey. Variabel independen adalah karakteristik informasi sistem informasi akuntansi manajemen dan variabel dependen adalah kinerja manajerial, sedangkan yang menjadi variabel moderasi adalah keberhasilan implementasi sistem informasi akuntansi. Jenis data yang digunakan adalah data primer dengan skala ordinal. Pengumpulan data dilakukan melalui survey dengan menyusun daftar pertanyaan yang ditujukan kepada responden. Operasionalisasi variabel ditunjukkan pada Tabel 1.

Populasi sasaran adalah pimpinan dan staf di BUMN berbadan hukum perseroan terbatas di Jawa Barat. Pengambilan sampel dilakukan berdasarkan pemilihan populasi dengan pertimbangan bahwa BUMN sudah menerapkan sistem pengelolaan perusahaan dengan baik, sehingga memudahkan pengambilan data yang ditujukan bagi manajer akuntansi, yaitu komponen yang langsung berhubungan dengan sistem informasi akuntansi yang telah ditentukan, maka untuk mengetahui berapa besarnya ukuran sampel digunakan rumus Slovin dengan tingkat kesalahan sebesar 5\% sebanyak 44. Jumlah sampel yang digunakan sebanyak 72 . Penelitian ini menggunakan teknik analisis data kuantitatif. Alat analisis menggunakan multiple regression analysis dengan bantuan program komputer SmartPLS.

\section{HASIL}

Variabel bebas adalah boardscope (BS), timelines (TL), aggregation (AG), integration (IG), dan digital skills (DS). Variabel terikat adalah kinerja manajerial. variabel moderasi adalah keberhasilan implementasi SIA. Analisis menggunakan Partial Least Square Path Modelling (PLS - PM) untuk menangani masalah multikolinearitas pada data (Tabel 2).

Evaluasi model pengukuran meliputi tiga tahap, yaitu convergent validity, discriminant validity dan composite validity. Convergent validity bertujuan untuk mengukur besarnya korelasi antara konstruk dengan variabel laten. Pengujian ini dilihat berdasarkan loading factor dan t-hitung. Nilai loading factor semua indikator diatas 0,7 dan nilai t-hitung $>1,725$ sehingga setiap indikator dapat mengukur masing-masing konstruknya dengan valid.

Pengujian discriminant validity, dapat dilihat berdasarkan nilai Average Variance Extracted (AVE). Nilai AVE untuk semua variabel memiliki nilai di atas 0,50 . Hal ini menunjukkan bahwa semua variabel observasi/indikator dapat menjelaskan masing-masing konstruknya lebih dari setengah variance, sehingga data yang digunakan dinyatakan valid. Nilai composite reliability dari semua variabel lebih besar dari 0,70 . Hal ini menunjukkan bahwa semua variabel memiliki reliabilitas yang baik.

Evaluasi model struktural dilakukan untuk melihat hubungan antar konstruk. Model struktural dievaluasi dengan menggunakan koefisien determinasi $\left(\mathrm{R}^{2}\right)$. Nilai R-square untuk variabel endogen KM sebesar 0,7820. Hal ini berarti variabel KM dapat dijelaskan oleh variabel $\mathrm{BS}, \mathrm{TL}, \mathrm{AG}, \mathrm{IG}, \mathrm{DS}$, dan SIA sebesar 78,20\%.

Indikator variabel laten boardscope dapat menjelaskan sebesar 71,32\%. Indikator variabel laten timeline dapat menjelaskan sebesar $67,23 \%$. Indikator variabel laten aggregation menjelaskan variabel laten sebesar 75,68\%. Indikator variabel laten integration dapat menjelaskan variabel laten sebesar $68,87 \%$. Indikator variabel laten keberhasilan implementasi sistem informasi akuntansi dapat menjelaskan sebesar $55,36 \%$. Indikator variabel laten kinerja manajerial dapat menjelaskan sebesar $66,10 \%$. Indikator variabel laten digital skills dapat menjelaskan sebesar 73,56\%.

\section{PEMBAHASAN}

Hubungan antara boardscope, timelines, dan integration dengan kinerja manajerial adalah tidak signifikan. Hubungan aggregation dengan kinerja manajerial adalah signifikan dengan arah positif yaitu sebesar 0,319. Hubungan integration dengan kinerja manajerial adalah tidak signifikan. Hubungan digital skills dengan kinerja manajerial adalah signifikan dengan arah positif yaitu sebesar 0,499. 
Keberhasilan implementasi sistem informasi akuntansi memperkuat pengaruh boardscope terhadap kinerja manajerial adalah signifikan dengan t-statistik sebesar 0,465. Nilai original sample estimate adalah positif sebesar 0,084 yang menunjukkan bahwa arah hubungan antara boardscope dengan kinerja manajerial adalah positif.

Keberhasilan implementasi sistem informasi akuntansi memperkuat pengaruh timelines terhadap kinerja manajerial adalah tidak signifikan dengan $\mathrm{t}$-statistik sebesar 1,392. Nilai original sample estimate adalah positif yaitu sebesar 0,351 yang menunjukkan bahwa arah hubungan antara timelines dengan kinerja manajerial adalah positif.

Keberhasilan implementasi sistem informasi akuntansi memperkuat pengaruh aggregation terhadap kinerja manajerial adalah tidak signifikan dengan $\mathrm{t}$-statistik sebesar 0,035 . Nilai original sample estimate adalah positif yaitu sebesar 0,007 yang menunjukkan bahwa arah hubungan antara aggregation dengan kinerja manajerial adalah positif.

Keberhasilan implementasi sistem informasi akuntansi memperkuat pengaruh integration terhadap kinerja manajerial adalah tidak signifikan dengan t-statistik sebesar 1,714. Nilai original sample estimate adalah negatif yaitu sebesar - 0,310 yang menunjukkan bahwa arah hubungan antara integration dengan kinerja manajerial adalah negatif.

Keberhasilan implementasi sistem informasi akuntansi memperkuat pengaruh digital skills terhadap kinerja manajerial adalah tidak signifikan dengan $\mathrm{t}$-statistik sebesar 0,162 . Nilai original sample estimate adalah negatif yaitu sebesar $-0,029$ yang menunjukkan bahwa arah hubungan antara digital skills dengan kinerja manajerial adalah negatif.

\section{KESIMPULAN}

Digital skills dan aggregation mempunyai pengaruh terhadap kinerja manajerial lebih tinggi dari pada pengaruh antara boardscope, timelines, dan integration. Lebih lanjut, dari lima variabel yang mempengaruhi kinerja manajerial secara langsung hanya digital skills yang merupakan variabel paling dominan dalam mempengaruhi keberhasilan penerapan SIA. Manfaat penelitian ini adalah memberikan masukan bagi perusahaan sebagai bahan pertimbangan untuk mendesain sistem akuntansi manajemen perusahaan (untuk menghasilkan karakteristik informasi sistem akuntansi manajemen) yang dibutuhkan perusahaan yang disesuaikan dengan strategi bisnis yang dapat memberikan dampak pada peningkatan kinerja manajerial.

\section{DAFTAR PUSTAKA}

Abdillah, W., \& Hartono, J. 2017. Pengaruh Motivasi Kerja Terhadap Kinerja Karyawan Melalui Kepuasan Kerja Sebagai Variabel Mediasi Pada Karyawan Pt . Borwita Citra Prima Surabaya. Agora.

Abdillah, W., \& Jogiyanto, H. 2015. Partial Least Square (PLS) Alternatif Structural Equation Modeling (SEM) dalam Penelitian Bisnis. In book.

Alsarayerh, A. M., \& Jain, A. 2018. The Impact of the Accounting Information System on Performance of Jordanian Commercial Banks. International Journal for Research in Applied Science \& Engineering Technology, 6(X), 238-241.

Anik dan Rico. 2018. Pengaruh Karakteristik Sistem Informasi Akuntansi Manajemen Terhadap Kinerja Manajerial Dengan Desentralisasi Sebagai Variabel Moderating. Akuntansi \& Keuangan. https://doi. org/10.1017/CBO9781107415324.004

Anwar, A. 2012. Pengaruh Komitmen Organisasional dan Pengetahuan Manajer Terhadap Keberhasilan Penerapan Sistem Informasi Akuntansi dan Dampaknya Terhadap Kinerja Keuangan Perusahaan (Survei Pada BUMN di Indonesia). Jurnal Dan Prosiding SNA - Simposium Nasional Akuntansi. https://doi.org/10.1017/CBO9781107415324.004

Bashirudin,A. 2015. Pengaruh Sistem Informasi Akuntansi Manajemen, Human Capital Dan Ketidakpastian Lingkungan Terhadap Kinerja Manajerial Pada Baitul Maal Wat Tamwil Di Wilayah Dki Jakarta. Universitas Islam Negeri Syarif Hidayatullah.

Choe, J. M. 2017. The Strategic Alignment of Management Account ing Information Systems, and Organizational Performance.

Fathi, Z. 2015. The relationship between corporate governance and earnings management in banks listed on Tehran Stock Exchange. Research Journal of Finance and AccountingOnline).

Gordon, L. A., \& Narayanan, V. K. 1984. Management accounting systems, perceived environmental uncertainty and organization structure: An empirical investigation. Accounting, Organizations and Society, 9(1), 33-47. https://doi.org/10.1016/03613682(84)90028-X

Handayani, S., \& Hariyati, H. 2014. Pengaruh Karakteristik Sistem Informasi Akuntansi Manajemen: Broadscope, Timeliness, Aggregated, Dan Integrated Terhadap Kinerja Manajerial Umkm. (Studi Pada Umkm Di Desa Wedoro, Kab. Sidoarjo). AKRUAL: Jurnal Akuntansi. https://doi. org/10.26740/jaj.v5n2.p184-204

Jogiyanto. 2017. Konsep Dasar Sistem Informasi. Konsep Dasar Sistem Informasi. 
Krigsman, M. 2012. Business Transformation with Cloud ERP [White paper]. NetSuite.

Laudon, M., Romanowicz, B. F., TechConnect Summit., H., \& K., R. 2012. Nanotech Conference \&amp; Expo 2012 : Nanotechnology 2012 : technical proceedings of the 2012 NSTI Nanotechnology Conference and Expo: June 18-21, 2012, Santa Clara, California, USA. TechConnect Briefs.

Lee, J. Y., Park, S., \& Baker, R. 2018. The moderating role of top management support on employees 'attitudes in response to human resource development efforts. Journal of Management and Organization, 24(3), 369-387. https://doi.org/10.1017/jmo.2017.37

Mathew, R. V., \& Panchanatham, N. 2016. An exploratory study on the development of women entrepreneurs: Indian cases. Journal of Research in Marketing and Entrepreneurship, 18(2): 232-247.

Mauliansyah, T. I. R., \& Saputra, M. 2020. Pengaruh Penerapan Sistem Informasi Akuntansi (Sia) Terhadap Kinerja Perusahaan (Studi Empiris Pada Umkm Di Kota Banda Aceh). Jurnal Ilmiah Mahasiswa Ekonomi Akuntansi, 4(4), 602-612. https://doi.org/10.24815/jimeka.v4i4.15321

Mia, L., \& Chenhall, R. H. 1994. The usefulness of management accounting systems, functional differentiation and managerial effectiveness. Accounting, Organizations and Society, 19(1), 1-13. https://doi.org/10.1016/0361-3682(94)90010-8

Pedroso, E., Gomes, C. F., \& Yasin, M. M. 2020. Management accounting systems: an organizational competitive performance perspective. Benchmarking, 27(6), 1843-1874. https://doi. org/10.1108/BIJ-12-2019-0547

Rumapea, M., Sinaga, J., \& Saragih, R. E. 2018. Pengaruh Penerapan Sistem Informasi Akuntansi Manajemen, Metode Pengukuran Kinerja Dan Sistem Penghargaan Terhadap Kinerja Manajerial Pada Rumah Sakit Estomihi Medan. Methomika : Jurnal Manajemen Informatika \& Komputerisasi Akuntansi, 2(1), 63-73.

Solechan, A., \& Setiawati, I. 2009. Pengaruh Karakteristik Sistem Akuntansi Manajemen dan Desentralisasi sebagai Variabel Moderating Terhadap Kinerja Manajerial (Studi Empiris Perusahaan Manufaktur di Kabupaten Semarang). Journal of Biomedical Informatics.

Suprantiningrum, S., \& Lukas, A. D. 2021. Sistem Informasi Akuntansi Manajemen, Pengendalian Manajemen terhadap Kinerja Manajerial dengan Variabel Moderating Teknologi Informasi. Owner, 5(1), 174-185. https://doi.org/10.33395/owner. v5i1.368

Susanto, A. 2015. Influence The Quality Of Accounting Information On The Implementation Good Study Program Governance. International Journal of Scientific \& Technology Research, 4(8), 326-335.

Susanto, A. 2017. Pengertian Sistem Informasi Akuntansi. Sistem Informasi Akuntansi.

Swanson, E. B., \& Ramiller, N. C. 1997. The Organizing Vision in Information Systems Innovation. Organization Science. https://doi.org/10.1287/ orsc.8.5.458

Tsui, J. S. L., \& Gul, F. A. 1996. Auditors'behaviour in an audit conflict situation: A research note on the role of locus of control and ethical reasoning. Accounting, Organizations and Society. https://doi. org/10.1016/0361-3682(95)00009-X

Warren, C. S., Reeve, J. M., \& Duchac, J. 2012. Financial and Managerial Accounting. In Management Accounting Research.

Widodo, H. \& Windi, C. 2011. Pengaruh Desentralisasi dan Karakteristik Informasi Sistem Akuntansi Manajemen Terhadap Kinerja Manajerial Pada PT. (Persero) Pelabuhan Indonesia III Cabang Tanjung Perak. Fe-Unimus.

Wilkin, C. L., \& Chenhall, R. H. 2010. A review of IT governance: A taxonomy to inform accounting information systems. Journal of Information Systems, 24(2), 107-146. https://doi.org/10.2308/ jis.2010.24.2.107

Wiryana, L., \& Augustine, Y. 2014. Pengaruh Karakteristik Informasi Sistem Akuntansi Manajemen Terhadap Kinerja Manajerial Dengan Variabel Moderasi Strategi Bisnis, Perceived Environmental Uncertainty (Peu), Ketidakpastian Tugas Dan Desentralisasi. Jurnal Magister Akuntansi Trisakti, 1(2), 155. https://doi.org/10.25105/jmat. v1i2.4936 
Tabel 1. Operasionalisasi Variabel

\begin{tabular}{|c|c|c|}
\hline Variabel & Dimensi & Indikator \\
\hline \multirow[t]{2}{*}{$\begin{array}{l}\text { Karakteristik sistem } \\
\text { informasi akuntansi } \\
\text { manajemen }(\mathrm{X})\end{array}$} & $\begin{array}{l}\text { 1. Broadscope (Lingkup } \\
\text { Luas) }\end{array}$ & $\begin{array}{l}\text { Fokus terhadap informasi yang berasal dari dalam dan luar organisasi. } \\
\text { Informasi keuangan dan non keuangan. } \\
\text { Berkaitan dengan estimasi peristiwa yang akan terjadi di masa yang akan datang. }\end{array}$ \\
\hline & $\begin{array}{l}\text { 2. Timeliness (Tepat } \\
\text { Waktu) } \\
\text { 3. Aggregation } \\
\text { (Agregasi) } \\
\text { 4. Integration (Integrasi) }\end{array}$ & $\begin{array}{l}\text { Frekuensi pelaporan } \\
\text { Kecepatan pelaporan } \\
\text { Kejelasan mengenai area yang menjadi tanggung jawab setiap manajer perusahaan. } \\
\text { Mencegah kemungkinan terjadinya overload informasi } \\
\text { Penyatuan tujuan. } \\
\text { Koordinasi antar segmen sub unit yang satu dengan sub unit yang lainnya }\end{array}$ \\
\hline Keberhasilan Penerapan & Kepuasan Pengguna & Tampilan \\
\hline $\begin{array}{l}\text { Sistem Informasi } \\
\text { Akuntansi (Z) }\end{array}$ & & $\begin{array}{l}\text { Terminologi dan Informasi Sistem Pembelajaran } \\
\text { Kapabilitas sistem }\end{array}$ \\
\hline & Penggunaan Sistem & $\begin{array}{l}\text { Frekuensi penggunaan } \\
\text { Acuan dalam tugas sehari-hari }\end{array}$ \\
\hline Kinerja Perusahaan (Y) & $\begin{array}{l}\text { Pencapaian target } \\
\text { perusahaan }\end{array}$ & $\begin{array}{l}\text { Pencapaian target terkait dengan produktivitas } \\
\text { Pencapaian target terkait dengan biaya } \\
\text { Pencapaian target terkait dengan kualitas } \\
\text { Pencapaian target terkait dengan pengiriman } \\
\text { Pencapaian target terkait dengan total aset } \\
\text { Pencapaian target terkait dengan pangsa pasar } \\
\text { Pencapaian target terkait dengan laba } \\
\text { Pencapaian target terkait dengan laba atas investasi } \\
\text { Pencapaian target terkait dengan volume penjualan }\end{array}$ \\
\hline
\end{tabular}

Tabel 2. Hasil Analisis Statistik

\begin{tabular}{lccccc}
\hline & Original Sample & Sample Mean & Std. Deviation & T Statistics & P Values \\
\hline AG -> KM & 0.306 & 0.325 & 0.153 & 1.999 & 0.046 \\
BS -> KM & -0.069 & -0.077 & 0.137 & 0.499 & 0.618 \\
DS -> KM & 0.459 & 0.413 & 0.218 & 2.105 & 0.036 \\
IG -> KM & 0.068 & 0.052 & 0.180 & 0.375 & 0.707 \\
KO -> KM & 0.063 & 0.081 & 0.115 & 0.546 & 0.585 \\
SIA -> KM & 0.186 & 0.166 & 0.224 & 0.833 & 0.405 \\
SIA-> AG -> KM & 0.019 & 0.016 & 0.212 & 0.089 & 0.929 \\
SIA->BS -> KM & 0.057 & 0.024 & 0.203 & 0.279 & 0.780 \\
SIA->DS -> KM & -0.056 & -0.049 & 0.209 & 0.268 & 0.789 \\
SIA->IG -> KM & -0.287 & -0.294 & 0.210 & 1.366 & 0.173 \\
SIA->KO -> KM & -0.014 & 0.026 & 0.179 & 0.081 & 0.936 \\
SIA-> TL -> KM & 0.363 & 0.344 & 0.253 & 1.434 & 0.152 \\
TL -> KM & -0.010 & 0.042 & 0.214 & 0.045 & 0.964 \\
\hline
\end{tabular}

